\title{
Exploring the Utility of Verbal and Visuospatial Working Memory for Identifying Children with Language Impairment
}

\author{
Dongsun Yim, Young Tae Kim, Yoonhee Yang \\ Department of Communication Disorders, Ewha Womans University, Seoul, Korea
}

Correspondence: Dongsun Yim, PhD Department of Communication Disorders, Ewha Womans University, 52 Ewhayeodae-gil, Seodamun-gu, Seoul 03760, Korea

Tel: $+82-2-3277-6720$

Fax: $+82-2-3277-2122$

E-mail: sunyim@ewha.ac.kr

Received: January 5, 2016

Revised: February 5, 2016

Accepted: March 7, 2016

This work was supported by the National Research Foundation of Korea grant funded by the Korean Government (NRF-2014S1A5A8017863).

This work was supported by the BK21 Plus project by the Korean Government.

This work was supported by the Ewha Womans University scholarship of 2015.

\begin{abstract}
Objectives: In the clinical setting, it is an important issue to find more efficient measures to identify language impairment equivalent to standardized language tests can be a useful tool in identification of language impairment. This study examined whether a combination of verbal and visuospatial working memory tasks can discriminate children with language impairment from those with typical language development. Method: A total of 36 children participated -18 children with language impairment (LI) and 18 typically developing (TD) children. Participants completed verbal working memory tasks (non-word repetition [NWR], sentence repetition [SR], Competing Language Processing Task [CLPT]), visuospatial working memory task (Matrix). Multivariate analysis, Pearson's product-moment correlation and discriminant analysis were used. Results: MANOVA results indicated that group differences for SR, CLPT scores were significant. Discriminant analysis conducted with all measures (NWR, SR, CLPT, Matrix) showed good sensitivity (83.3\%) and specificity (94.4\%) in distinguishing between TD and LI groups. Conclusion: Children with LI exhibited deficits in verbal tasks (SR, CLPT) rather than visuospatial task (Matrix) relatively. However, visuospatial ability was not correlated any standardized language test scores in LI group although their performance was not behind. Nevertheless, a combination of various working memory tasks can be a useful tool in discrimination of children with LI from their TD peers.
\end{abstract}

Keywords: Verbal, Visuospatial, Working memory, Discriminate analysis
언어능력은 한 가지 요소로 설명될 수 없으며, 복합적인 인지적 기술로서 다양한 처리 기제와 서로 상호작용하며 발달이 이루어진 다. 언어발달지연 또는 언어장애아동의 어려움은 언어영역에서뿐 만 아니라 다양한 인지처리 과제 수행에서도 나타날 수 있다. 특히, 5-6세 경의 언어장애아동의 경우 또래 일반아동에 비해 억제, 전환, 감정조절 및 계획과 같은 집행기능에서 더 낮은 수행을 보였으며, 구어 및 시공간적 작업기억 과제에서도 유의하게 어려움을 보이는 것으로 보고된 바 있다(Archibald \& Gathercole, 2006; Ellis Weismer, Evans, \& Hesketh, 1999; Mainela-Arnold, Evans, \& Coady, 2010; Marini, Gentili, Molteni, \& Fabbro, 2014; Marton, 2008).

특히 언어장애아동에게서 흔히 보고되는 구어 작업기억의 결함 이 이들의 부족한 언어능력을 뒷받침한다는 학설들이 주장되고 있 다(Ellis Weismer et al., 1999; Montgomery, 2002). 음운저장결함 가설(phonological storage deficit hypothesis)에 따르면, 이러한 구 어 작업기억에서의 어려움은 이들의 언어학적 발달 및 기능에 영향 을 미친다. 즉, 구어로 제시되는 새로운 음소를 습득하고 단어의 정 보와 형태를 저장 및 회상하는 구어 작업기억 능력은 언어능력에 중요한 역할을 하며, 이러한 저장 및 회상 능력의 부족은 언어장애 의 주된 요인이 될 수 있는 것이다(Archibald \& Gathercole, 2007; Bishop, 2006; Ellis Weismer et al., 1999; Montgomery, 2002). 구어 작업기억 능력의 제한은 언어발달지연 아동들의 일상생활 속 의사 소통 상호작용 효율의 저하를 가져오고, 더 적은 발화수 산출로 이 어지게 하며, 부적절한 단어를 선택하게 한다(Marini et al., 2014). 반면 언어장애아동 중 구어작업기억 능력이 또래 일반아동 수행의 평균 범주에 있을 경우 언어기술 측정 과제에서 더 나은 수행을 보 이며, 더 많은 발화를 산출하기도 하였다(Botting \& Conti-Rams- 
den, 2001). 그러므로 구어 작업기억 능력은 이들의 부족한 언어능 력 향상을 이끌어낼 수 있는 주요 요소로서의 가능성을 지니고 있 다고볼수 있다.

구어 작업기억 용량을 측정하는 과제로는 비단어 따라말하기 (Dollaghan \& Campbell, 1998; Gathercole, Willis, Baddeley, \& Emslie, 1994), 문장 따라말하기(Kamhi \& Catts, 1986; Stokes, Wong, Fletcher, \& Leonard, 2006), 경쟁 언어 처리 과제(Ellis Weismer et al., 1999; Gaulin \& Campbell, 1994) 등이 있다. 이 과제들은 모두 언어장애아동을 판별하는 임상적 지표로 수많은 선행연구들을 통 해 그 가능성이 입증되었다(Ellis Weismer et al., 1999; MainelaArnold et al., 2010; Stokes et al., 2006).

비단어 따라말하기와 문장 따라말하기는 모두 ‘음운 처리, 표상 그리고 저장 능력'을 측정할 수 있는 과제로, 선행연구에서 이 두 과 제의 수행 간 유의한 정적 상관관계를 밝힌 바 있다(Bishop, North, \& Donlan, 1996; Conti-Ramsden, Botting, \& Faragher, 2001; Kamhi \& Catts, 1986). 그러나 비단어 따라말하기는 상대적으로 아동 이 이미 지니고 있는 언어 능력을 최대한 배제할 수 있는 측정도구 인 반면, 문장 따라말하기는 기존 어휘 또는 문법적 구문 구조의 이 해 능력, 언어학적 지식등과 같이 언어 능력을 요구하는 측정도구 일 수 있다(MacWhinney, Feldman, Sacco, \& Valdés-Pérez, 2000). 반면 경쟁 언어 처리 과제는 단지 비단어나 문장 등을 그대로 반복 하여 기억하는 능력 만을 측정하는 것에서 벗어나 들려주는 문장 에 대해 의미적인 정오판단을 하는 실제적인 언어적 수행과 함께 구어적 작업 기억의 사용이 역동적으로 이루어질 수 있는지 평가 할 수 있는 도구로 개발된 과제이다(Gaulin \& Campbell, 1994).

특히 영어권에서는 만 5세 언어장애아동을 대상으로 비단어 따 라말하기 과제를 실시하였을 때 언어장애아동을 언어장애로 판별 하는 민감도(sensitivity)는 66\%, 일반아동을 일반아동으로 판별하 는 특이도(specificity)는 85\%로 분류할 수 있어 임상적 도구로서의 유용성을 입증한 바 있다(Conti-Ramsden, 2003). 이보다 더 높은 연령대인 만 7세의 아동들을 대상으로 3-4 음절의 비단어 따라말 하기 과제를 수행한 결과, 언어장애아동과 일반아동을 $98 \%$ 의 정확 도로 진단하여 상대적으로 높은 연령대의 아동일수록 진단 정확도 는 높게 나타날 수 있음을 확인할 수 있었다(Dollaghan \& Campbell, 1998).

또한 언어권에 따른 차이도 나타나는데 앞서 언급한 영어권의 연 구뿐 아니라 스페인어(Calderon \& Guiterrez-Clellen, 2003), 광둥 어(Stokes et al., 2006), 한국어(Hwang, 2014; Yang, Yim, Kim, \& $\mathrm{Han}, 2013)$ 권에서도 비단어 따라말하기 과제를 사용한 연구도 있 었다. 스페인어를 사용하는 만 4 세의 아동을 대상으로 비단어 따
라말하기 과제를 사용한 연구에서는 영어권에서처럼 언어장애아 동들이 또래 일반아동에 비해 유의하게 부족한 수행을 보였다. 그 러나, 만 4-5세의 아동을 대상으로 광둥어 비단어를 사용한 따라 말하기 과제를 수행한 연구에서는 집단 간 차이가 나타나지 않았 다. 한국어권에서는 연령대 별로 차이가 나타났다. 한국어를 사용 하는 만 2-6세의 어린 학령전기 아동들의 경우 비단어 따라말하기 능력에서 어휘발달지체 아동이 또래 일반아동에 비해 유의하게 낮 았다(Yang et al., 2013). 그러나, 초등 3-5학년의 비교적 높은 연령대 의 읽기이해부진 및 또래 일반아동을 대상으로 했을 때 비단어 따 라말하기 수행의 집단 간 차이는 유의하지 않았다(Hwang, 2014). 이와 같이 아동의 언어권 및 연령대에 따라 비단어 따라말하기 과 제의 언어장애아동 판별력은 달라질 수 있다. 또한, 특정 언어권에 서 비단어 따라말하기 과제가 언어장애아동을 확인하는 유용한 도구로 확인되었을지라도, 장애 판별을 목적으로 사용할 때에는 단일 과제를 단독으로 활용되기 보다는 여러 다른 요소들과 함께 고려되어야 함을 제안하기도 하였다(Ellis Weismer et al., 2000).

비단어 따라말하기 과제와 더불어 문법 형태소 사용도 함께 측 정할 수 있는 문장 따라말하기 과제는 미국의 표준화 언어검사도 구인 Clinical Evaluation of Language Fundamentals-Revised (CELFR; Semel, Wiig, \& Secord, 1989)와 Test of Language DevelopmentPrimary (TOLD-P; Newcomer \& Hammill, 2008)에도 수록되어 있는 유용한 도구이다. 만 10-11세의 언어장애아동 160 명, 또래 일 반아동 100 명을 대상으로 임상적 지표로서의 잠재성을 지닌 비단 어 따라말하기, 문장 따라말하기 과제를 수행한 결과 문장 따라말 하기는 비단어 따라말하기보다도 높은 판별력을 지닌 과제임을 입 증하였다(Conti-Ramsden et al., 2001). 즉, 이 연구에서 문장 따라 말하기의 경우 민감도는 $90 \%$, 특이도는 $85 \%$, 비단어 따라말하기 의 경우 민감도는 $78 \%$, 특이도는 $87 \%$ 로 나타나 비단어 따라말하 기에 비해 문장 따라말하기의 판별력이 더욱 높은 것으로 나타났 다. 국내의 연구에서도 만 2-3세의 말 늦은 아동과 일반아동을 대 상으로 비단어 따라말하기와 문장 따라말하기 수행 능력을 비교 했을 때 문장 따라말하기에서만 말 늦은 아동의 선별이 가능하였 다(Oh \& Yim, 2013). 그러나, 초등학교 3-5학년의 비교적 높은 연령 의 읽기이해부진 아동들은 문장 따라말하기 과제 수행에서는 어 려움을 겪었지만, 비단어 따라말하기 과제 수행에서는 또래 일반 아동과 유사한 수행을 보였다. 즉, 한국어권에서 연령대에 상관없 이 문장 따라말하기 과제의 보다 높은 임상적 유용성을 확인해 볼 수 있다(Hwang, 2014).

앞서 설명한 비단어 따라말하기 및 문장 따라말하기 과제가 즉 각적인 음운 작업기억 능력을 측정하는 도구로 알려져 있는 반면 
(Ellis Weismer \& Thordardottir, 2002), 구어 작업기억 능력과 더불 어 구문이해능력을 복합적으로 측정할 수 있는 경쟁 언어 처리 과 제는 언어처리 과정 중 언어학적 이해와 구어 정보저장 간 균형에 초점을 맞춘 과제이다(Ellis Weismer et al., 1999; Just \& Carpenter, 1992). Montgomery (2000)는 언어장애아동들이 특히 이중 처리를 요하는 높은 요구수준의 과제 수행에서 정보 처리에서의 어려움을 나타낸다고 보았다. 이와 관련하여 Ellis Weismer 등(1999)의 연구 에서는 언어장애아동들이 또래 일반아동에 비해 경쟁 언어 처리 과제 수행에서 문장이해 처리에서는 부족함을 보이지 않았으나, 문 장의 마지막 단어(목표단어)를 회상할 때에는 유의하게 어려움을 보였다고 보고하였다. 즉, 언어장애아동들은 또래 일반아동들에 비해 근본적으로 일시적 저장 공간이 작으며, 과제 수행 시 긴 문장 을 이해해야 할 때 언어장애아동들의 경우 문장의 마지막 단어들 과 같은 구어 정보들의 저장을 위해 더 적은 저장공간을 남겨놓기 때문인 것으로 보았다(Ellis Weismer \& Thordardottir, 2002).

구어 작업기억 능력과 더불어 시각적 이미지 및 공간적 정보를 저장 및 조작하는 역할을 담당하는 시공간적 작업기억 영역에서도 언어발달지연 아동의 결함이 나타나는 것으로 보고되었다(Van der Lely \& Howard, 1993). Leonard (1998)에 의하면, 또래 일반아 동들과 유사한 비언어성 지능 점수를 획득하는 단순언어장애 아동 일지라도 언어 결함 뿐만 아니라 비언어적 처리 결함을 나타낸다고 보았는데, 이들의 어려움은 제한된 작업기억용량(Ellis Weismer et al., 1999), 제한된 처리속도(Kail \& Salthouse, 1994; Miller, Kail, Leonard, \& Tomblin, 2001), 에너지 또는 효율성의 축소(Bishop, 1997), 전반적 처리 제한(Ullman \& Pierpont, 2005) 등으로 설명해 왔다. 즉, 언어에 한정된 어려움을 보인다고 보았던 단순언어장애 아동들 마저 공간적 처리 능력(Kamhi, Catts, Mauer, Apel, \& Gentry, 1988), 이미지 생성(Johnston \& Ellis Weismer, 1983)과 같은 인 지 능력에서도 어려움을 나타낸 것이다. 이와 같은 어려움은 단순 언어장애 아동들이 단지 시각적 심상을 생성해내는 자체에 어려움 을 보인다기 보다는, 이 시각적 심상을 또래 일반아동에 비해 잘 유 지하고 적절히 사용하는 것에 어려움을 보이는 것으로 보았다. 이 러한 시각적 심상은 또한 어휘 이해와 같은 언어 능력과도 정적인 상관관계가 있음을 밝혀 시공간적 정보 처리 능력이 언어와 무관 하지 않음을 확인해볼 수 있다(Kamhi, Catts, Koenig, \& Lewis, 1984). 단순한 숫자 폭 기억하기 과제에서 가리키기(pointing)와 같 은 비구어적 반응을 요구하는 시각적 제시방법을 사용하여 언어적 결함의 개입 가능성을 축소시킬지라도, 단순언어장애 아동들은 일반아동에 비해 유의한 어려움을 보였다. 즉, 일반아동의 경우 시 각적 정보를 구어적 형태로 변형시킬 수 있는 능력을 지니고 있었던
반면, 단순언어장애 아동은 숫자를 회상하는 데에 비효율적인 시 각적 코드 자체에만 의존하는 모습을 보였다고 분석하였다(Gillam, Cowan, \& Marler, 1998). 특히 구어적 시연의 도움을 받을 수 없어 이름 붙이기 어려운 추상적 패턴을 회상해야 할 경우 단순언 어장애 아동들의 비구어적 작업기억 과제 수행의 어려움은 명확히 드러나는 것으로 보인다. 뿐만 아니라 시공간적 처리 과제에서는 어 느 정도의 운동 기술을 요하는데, 정교화된 운동 능력의 발달이 시 공간적 처리 및 기억 과제를 수행하는 데에 요구될 수 있음을 시사 하기도 하였다(Hick, Botting, \& Conti-Ramsden, 2005).

반면, 언어장애아동들의 작업기억 상의 결함은 구어 영역에 한 정된 것으로 시공간적 작업 기억 과제에서는 수행 결함을 나타내지 않은 연구 결과가 제시되기도 하였다(Archibald \& Gathercole, 2006; Bavin, Wilson, Maruff, \& Sleeman, 2005). 이는 언어장애아동들의 작업기억 결함이 구어 영역에 한정되어 나타날 수 있으며, 부족한 구어 단기 및 작업기억 능력이 언어에서의 새로운 음운적 형태를 학습하는 것의 어려움으로 이어질 수 있다고 보았다(Archibald \& Gathercole, 2006). 즉, 언어장애아동들의 작업기억 상의 결함이 전 반적인 영역에 걸쳐 나타나는 것이 아닌 구어 영역에 한정적이라면, 이들의 잔존하는 시공간적 영역에서의 처리 및 저장 능력이 이들의 언어능력을 증진시키는 유용한 기제로 활용될 수 있는 가능성에 대해 논의해볼 수 있다(Bavin et al., 2005).

이에 본 연구에서는 임상 현장에서 현재 사용하고 있는 표준화 언어검사도구 외에도 구어 및 시공간적 작업기억 과제들이 절차 및 시간적인 측면에서 탄력적으로 운용될 수 있는 유의미한 임상적 도 구로 적절히 활용될 수 있는지 탐색해보고자 하였다. 즉, 언어장애 유무를 판별하는 데에 유용한 것으로 나타난 작업기억 과제들이 높은 수준의 언어장애 진단 정확도를 지니고 있는지 그 가능성에 대해 논의해보는 것은 임상적 의의가 있다. 이에 본 연구에서는 구 어 및 시각적으로 다양한 유형의 자극을 제시하는 작업기억 과제 들의 수행결과를 조합하여 표준화 언어검사 결과에 준하는 언어발 달지연 여부를 파악할 수 있는지 알아보고자 하였다.

이에 대한 본 연구의 세부 연구질문은 아래와 같다.

첫째, 아동의 구어 및 시공간적 작업기억 수행은 집단 간(언어장 애아동/일반아동) 유의한 차이를 보이는가?

둘째, 언어장애아동 및 또래 일반아동 집단 각각에서 표준화 언 어검사와 유의한 상관관계를 보이는 작업기억 과제의 하위유형은 무엇인가?

셋째, 구어 및 시각적으로 다양한 유형의 자극을 제시하는 작업 기억 수행결과의 조합은 표준화 언어검사 결과에 준하는 언어장애 판별력을 지닐 수 있는가? 


\section{연구 방법}

\section{연구대상}

본 연구는 서울 및 수도권 지역에 거주하는 만5-6세의 언어장애 아동 18 명(남 10 명, 여 8 명), 그리고 생활연령을 \pm 3 개월 범위 내로 일치시킨 또래 일반아동 18 명(남 7 명, 여 11명), 총 36 명을 대상으로 하였다.

본 연구에 참여한 언어장애아동은 (1) 아동의 주양육자 또는 초 등학교 및 유치원 담임교사에 의해 인지 및 신체능력이 정상 범주 에 속하는 것으로 보고되고, (2) 카우프만 아동용 지능검사(Korean Kaufman Assessment Battery for Children, K-ABC; Moon \& Byun, 2003)의 비언어성 지능지수가 85점(-1 SD) 이상이며, (3) 수 용 및 표현어휘력검사(Receptive and Expressive Vocabulary Test, REVT; Kim, Hong, Kim, Jang, \& Lee, 2009) 결과 수용 및 표현어휘 력점수 모두 자신의 생활연령 기준에서 -2 SD 미만이며, (4) 정서, 행동, 감각(시각 및 청각), 사회적 상호작용 등의 문제가 없고, 기타 신경학적 결함의 이력이 없는 아동으로 선정하였다.

본 연구에 참여한 일반아동은 (1) 아동의 주양육자 또는 초등학 교 및 유치원 담임교사에 의해 인지 및 신체능력이 정상 범주에 속 하는 것으로 보고되고, (2) 카우프만 아동용 지능검사(K-ABC; Moon \& Byun, 2003)의 비언어성 지능지수가 85점(-1 SD) 이상이 며, (3) 수용 및 표현어휘력검사(REVT; Kim et al., 2009) 결과 수용 및 표현어휘력점수가 모두 정상 범주(-1 SD 이상)에 속하며, (4) 정 서, 행동, 감각(시각 및 청각), 사회적 상호작용 등의 문제가 없고, 기 타 신경학적 결함의 이력이 없는 아동으로 선정하였다.

언어장애아동 집단의 평균 생활연령은 70.94 개월 $(\mathrm{SD}=3.96)$, 일 반아동 집단의 평균 생활연령은 68.39 개월 $(\mathrm{SD}=4.89)$ 이었다. 언어 장애아동 집단의 동작성 지능 평균은 103.11점(SD=13.646)이고, 일반아동 집단의 동작성 지능 평균은 109.83 점 $(\mathrm{SD}=9.72)$ 이었다. 또한, 언어장애아동 집단의 수용어휘력은 48.39 점 $(\mathrm{SD}=7.76)$, 일반 아동 집단의 수용어휘력은 68.28 점 $(\mathrm{SD}=10.44)$ 이고, 언어장애아 동 집단의 표현어휘력은 55.94 점( $\mathrm{SD}=11.09)$, 일반아동 집단의 표 현어휘력은 74.06 점 $(\mathrm{SD}=9.78)$ 이었다.

두 집단의 통제가 잘 이루어졌는지 확인하기 위해 일원분산분석 (one-way ANOVA)을 실시한 결과, 연령 및 비언어성 지능에 통계 적으로 유의한 차이가 없었고, 수용어휘력 $\left(F_{(1,34)}=42.09, p<.001\right)$ 및 표현어휘력 $\left(F_{(1,34)}=27.01, p<.001\right)$ 에 대한 집단 간 차이가 통계적 으로 유의하게 나타났다. 두 집단 아동들의 생활연령, 비언어성 지 능, 수용 및 표현어휘력 점수의 평균 및 표준편차는 Table 1에 제시 하였다.
Table 1. Participants' characteristics

\begin{tabular}{lccc}
\hline & LI (N=18) & NL (N=18) & $F$ \\
\hline Age (mo) & $70.94(3.96)$ & $68.39(4.89)$ & 2.968 \\
Nonverbal IQ & $103.11(13.65)$ & $109.83(9.72)$ & 2.899 \\
REVT-R $^{\text {a }}$ & $48.39(7.76)$ & $68.28(10.44)$ & $42.09^{* *}$ \\
REVT-E $^{\text {b }}$ & $55.94(11.09)$ & $74.06(9.78)$ & $27.01^{* *}$
\end{tabular}

Values are presented as mean (SD).

$\mathrm{LI}=$ children with language impairment; $\mathrm{NL}=$ children with normal language.

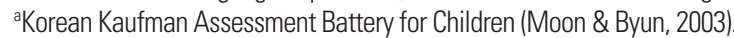

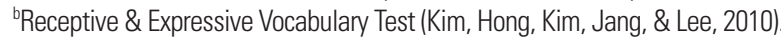
${ }^{* *} p<.001$.

\section{연구 도구}

본 연구에서는 만 5-6세의 언어장애아동 및 또래 일반아동들의 작업기억 능력을 측정하기 위해 구어 및 시공간적 작업기억으로 나 누어 언어장애 판별에 유용한 임상적 도구가 존재하는지, 언어장 애아동 및 또래 일반아동 집단 각각에서 표준화 언어검사와 유의 한 상관관계를 보이는 작업기억 과제의 하위유형은 무엇인지, 그리 고 언어장애 판별을 위해 유용한 작업기억 하위항목의 조합이 표 준화 언어검사에 의해 분류된 언어장애 및 일반아동 집단 분류의 결과와 얼마나 부합하는지 확인하고자 아래와 같은 연구 과제들 을 실행하였다.

\section{작업기억 과제}

구어작업기억

비단어 따라말하기(non-word repetition, NWR): 비단어 따라말 하기는 아동에게 청각적으로 비단어를 제시하고, 아동이 제시된 비 단어를 즉시 따라 말하도록 고안된 검사도구이다. 본 연구에서는 Dollaghan과 Campbell (1998)의 연구에 근거하여 한국어의 언어적 특성을 고려한 Lee, Yim 그리고 Sim (2012)의 비단어 따라말하기 과 제를 사용하였다. 이 과제는 단어 유사성이 낮은 비단어를 기초로 2 음절에서 6 음절까지 각각 4 개씩 최종 20 개의 단어로 구성하였다.

검사는 소음이 없는 조용한 장소에서 아동과 검사자 간 일대일 로 진행되었다. 검사자는 아동에게 시각적인 단서 없이 각 음절 당 약 2 초 간격으로 제시되는 비단어 한 개씩을 헤드폰을 통해 듣게 하고 즉시 반복하여 따라 말하게 하였다. 비단어 음성 파일은 한국 인 성인 여성의 음성으로 녹음되었으며, 2 음절을 시작으로 3 음절, 4 음절, 5 음절, 6 음절 길이 순으로 제시되었다. 컴퓨터 파일로 검사 를 실시하기 전, 검사자는 과제를 수행하는 방법에 대한 설명을 아 동에게 구어로 전달하였다. 먼저, 똑같이 따라 말하는 것에 대한 이 해를 돕기 위해 본 과제의 명칭을 '앵무새 놀이'로 명명하고, 비단어 로 연습 문제를 실시하기에 앞서 아동이 과제의 방법을 정확히 이 
해하는지 확인하기 위해 충분한 연습 문항을 실시하였다. 연습 문 항을 통해 아동이 과제를 이해한다고 판단되면, 컴퓨터 음성파일 을 통해 비단어를 들려주었다. 검사자는 연습 문항에서 아동이 헤 드폰을 통해 자극이 잘 들리는지 확인하였으며, 아동에게 들리는 각 단어의 길이가 점차적으로 늘어난다는 것을 본 과제가 시작되 기 전 미리 숙지할 수 있도록 하였다.

과제의 채점방식은 2 가지로, (1) 1 번부터 20 번까지 총 20 개의 비 단어 중에서 정조음한 비단어에 1 점, 오조음한 비단어에 0 점을 부 여하여 총 20점 만점으로 기재한 단어점수와, (2) 과제에서 제시된 총 80 개의 음절 중 각 문항별 음절에 따라 정조음한 음절에 1 점, 오 조음한 음절에 0 점을 부여하여 총 80 점 만점으로 기재한 음절점수 로 총점을 각각 산출하였다.

문장 따라말하기(sentence repetition, SR): 문장 따라말하기는 $\mathrm{Ahn}$ 과 Kim (2000)의 연구에서 사용된 것으로 검사문장은 총 36 개로 구성되어있다. 문장 따라말하기 과제의 난이도는 문장의 길이 와 문장구조 유형에 따라 단문 3 어절, 단문 5어절, 복문 5어절(접 속), 복문 5 어절(내포) 총 4 가지의 유형으로 구성되었다. 문장의 예 시로 단문 3 어절 문항의 경우 '그림을 연필로 그려요', 단문 5 어절은 '동생이 작은 칫솔로 이빨을 닦아요', 복문 5어절(접속)은 '동생이 바지를 입고 양말을 신어요', '복문 5어절(내포)는 '친구가 잠을 자 는 강아지를 깨워요'가 있다.

검사 절차는 다음과 같다. 검사자가 아동에게 들려주는 말을 똑 같이 따라 말하는 과제의 수행방법에 대해 충분히 설명한 후 연습 문항을 실시하고 아동이 과제에 대해 충분히 이해했다고 판단되면 본 검사를 실시하였다. 검사는 검사자가 아동에게 녹음파일을 통 해 아동에게 문장을 들려주면 아동은 문장을 들은 즉시 정확하게 따라 말하도록 하였다. 검사자는 아동의 반응을 들으며 즉각적으 로 정오반응을 표시하며 전사하였으며, 녹음기로 녹취하였다. 검사 종료 후 검사자는 전사된 내용과 녹취 파일을 비교하며 재검 절차 를 거쳤다.

과제의 채점방식은 2 가지로, (1) 1 번부터 35 번까지 총 35 개의 문 장 중에서 문장의 모든 부분에서 정확히 따라 말한 문장에 1 점, 부 분적으로라도 틀린 문장에 0 점을 부여하여 총 35 점 만점으로 기재 한 문장점수와, (2) 과제에서 제시된 총 157 개의 어절 중 각 문항별 어절에 따라 정조음한 어절에 1 점, 오조음한 어절에 0 점을 부여하 여 총 157 점 만점으로 기재한 어절점수로 총점을 각각 산출하였다. 또한, 대상들의 조음음운 산출 능력이 과제에 미치는 영향을 배제 하기 위해 아동의 단순 오조음으로 판단되는 것은 오반응으로 측 정하지 않았다.
경쟁 언어 처리 과제(Competing Language Processing Task, CLPT): 경쟁 언어 처리 과제는 언어적 정오판단을 수행함과 동시 에 구어 작업기억 용량을 측정하기 위한 이중 부하(dual-loaded)가 적용되는 과제로, 기존 선행연구에서 숫자, 철자, 단어, 문장 등을 그대로 반복해서 말하는 과제들과 차별점을 둔 과제이다(Gaulin \& Campbell, 1994). 본 과제는 아동에게 들려준 문장에 대해 각각 의 미적인 정오를 판단하는 것(예/아니오)과 난이도에 따라 그룹화된 문장들의 마지막 단어들을 기억하고 회상하는 과제(단어회상)로 구성되어 있다. 본 연구에서는 Kim과 $\operatorname{Yim}$ (2012)의 한국어 문장 폭 기억하기 과제(CLPT)를 사용하였다.

과제의 난이도는 6단계로 이루어져 있고, 각 단계로 올라갈수록 듣고 판단 및 회상해야 하는 수가 증가한다. 즉, 난이도 1 에서는 문 장 1 개, 난이도 2 는 문장 2 개, 난이도 3 은 문장 3 개, 난이도 4 는 문 장 4 개, 난이도 5 는 문장 5 개, 난이도 6 은 문장 6 개이며 각 난이도는 2 세트씩 총 42 개의 문장으로 구성된다. 모든 문장 구조는 3 어절로 이루어져 있으며 ‘정오판단' 과제에서는 각각의 문장을 듣고 문장 의 의미가 맞는지/틀리는지에 대해 즉각적으로 반응해야 한다. '단 어회상'은 그룹화된 각 문장의 마지막 단어들을 기억하고 있다가 각 단계의 마지막에 반응하는 것으로 난이도에 따라 문장의 수도 증가하기 때문에 회상해야 하는 마지막 단어의 수도 증가한다.

예를 들어, 난이도 1 은 “거인은 작은 사람이다."의 1 개의 문장을 듣고 의미판단 후 마지막 단어인 '사람이다'를 기억해야 하며, 난이 도 2 의 경우, "환자는 아픈 사람이다.", "우유는 색깔이 하얗다." 2 개의 문장을 연달아 들은 직후, 의미를 판단하여 예 또는 아니오로 정오판단을 하고, 최종적으로 각 2 문장의 마지막 단어인 사람이 다', ‘하얗다' 중 기억하는 단어들을 모두 회상해서 답해야 한다.

음성 파일은 한국인 성인 여성에 의해 2 개의 연습 문항과 본 문 항 42 개, 총 44 개의 문장이 녹음되었다. 각 문장은 약 $2,000 \mathrm{~ms}$ 간 격으로 녹음되어 있고, 아동은 다음 문장이 제시되기 전 약 2,000 $\mathrm{ms}$ 의 시간 내에 각 문장에 대한 ‘예/아니오'로 정오판단을 하고, 모 든 문장들이 제시되면 각 문장들의 마지막 단어들을 모두 회상하 여 답한다.

검사는 검사자와 아동이 일대일로 앉을 수 있도록 준비된 조용 한 방에서 개별적으로 실시하였다. 2 개의 연습 문항에서 검사자가 아동이 과제에 대해 정확히 숙지할 수 있도록 설명하고, 충분히 과 제 내용을 숙지했다고 판단되었을 때 본 검사를 실시하였다. 단서 는 연습 문항에서만 제시하며 본 과제를 수행할 때는 어떠한 단서 도 제공하지 않았다. 본 검사가 시작되기 전 검사자는 아동에게 들 려주는 문장이 점점 많아진다는 것을 미리 설명하여 아동이 숙지 할 수 있도록 하였다. 아동에게 들리는 문장에 대해 ‘예/아니오’로 
정오판단을 하도록 하였으며, '단어 회상'은 난이도별 문장을 모두 듣고 '각 문장의 마지막 단어는 무엇이었나요?'라는 음성이 제시되 면 기억하고 있는 마지막 단어를 모두 회상하도록 하였다. 이 때, 난 이도 내 문항 순서에는 상관없이 기억나는 단어들을 모두 말하도 록 하였다. 검사는 1 단계부터 6 단계까지 중단 없이 이루어지며, 검 사자는 과제 도중 아동에게 어떠한 피드백도 제공하지 않았다.

과제의 채점방식은 '정오판단' 과제의 경우, 정반응에 1 점, 오반 응에 0점, '단어회상'의 경우, 아동이 회상한 단어의 수만큼 1 점씩 부여하였다. 이때, 난이도 내 문항의 순서는 상관없이 정반응 한 회 상단어에 대해서는 모두 정반응으로 처리하였으며, 아동이 문장의 마지막 단어가 아닌 전체 문장을 똑같이 회상한 경우에도 정반응 으로 판단하여 1 점으로 처리하였다. 단, 문장구조의 어절 위치를 바꿔 말하거나 의미는 동일하지만 마지막 단어가 같지 않은 경우는 오반응으로 간주하였다.

\section{시공간적 작업기억 - 매트릭스(Matrix)}

본 과제는 작업기억의 하위 영역 중 하나인 시공간 스케치패드 (visuospatial sketch-pad)의 용량을 측정할 수 있는 과제(Gathercole \& Pickering, 2000)로, 본 연구에서는 Gathercole과 Pickering (2000)의 매트릭스 과제를 수정 보완한 Kim과 Yim (2012)의 과제 를 사용하였다.

과제는 컴퓨터 화면에 $3 \times 3$, 총 9 개로 이루어진 정사각형 검정색 매트릭스에 난이도에 따라 다른 개수만큼의 주황색 매트릭스가 $500 \mathrm{~ms}$ 간격으로 연속적으로 깜박이도록 구성되어 있다. 이후 정 지 화면이 나타나고, 그 다음 컴퓨터 화면에 다시 9 개의 빈 검정색 매트릭스가 제시되었다. 이때 아동은 주황색 매트릭스를 순서대로 기억하여 손가락으로 빈 매트릭스를 가리키는 방법(forward)과 반 대로 기억하여 빈 매트릭스를 가리키는 방법(backward)에 따라 과 제를 수행하였다. 과제의 난이도는 4단계로 구성되어 있고, 주황색 으로 깜박거리게 되는 칸이 난이도 1 에서는 2 칸, 난이도 2 에서 3 칸, 난이도 3 에서 4 칸, 난이도 4 에서 5 칸으로 각 단계별로 1 칸씩 증가 한다. 본 과제는 예제 5 문항과 18 개의 검사 문항으로 구성되어 있으 며, 각 난이도별 검사 문항 수는 난이도 1 과 2 는 4 문항, 난이도 3 과 4 는 5 문항으로 총 18 개의 문항으로 구성되었다.

과제 수행의 절차는 다음과 같다. 조용한 방에서 검사자와 아동 이 일대일로 앉아 개별적으로 실시하였다. 검사자는 아동에게 컴퓨 터 화면에 주황색 불이 나타났다가 사라질 것이며, 이 순서를 기억 하고 있다가 순행(forward)과제 수행 시에는 아동이 본 것과 '순서 대로', 역행(backward)과제 수행 시에는 아동이 본 것과 ‘반대로/거 꾸로' 수행해야 함을 설명하였다. 본 과제는 제시되는 자극을 순서
대로 또는 거꾸로 기억해야 하는 특성에 따라 아동이 '순서대로'와 ‘반대로/거꾸로' 각각에 대한 개념을 인지하여 버튼을 누를 수 있도 록 충분히 설명하였다. 이 후 연습하는 단계를 거쳐서 아동이 과제 수행의 규칙을 충분히 숙지하였다고 판단되었을 때 본 문항을 실시 하였다.

과제의 채점방식은 아동이 정반응 한 경우 1 점, 오반응 한 경우 0 점으로 처리하였다. 검사자는 아동이 정반응 한 경우와 오반응 한 경우 모두 동일하게 반응해주었다.

\section{자료분석 및 결과처리}

본 연구에서 사용된 과제의 점수는 모두 정반응 1 점, 오반응 0 점 으로 계산되었으며, 모든 통계적 분석은 SPSS ver. 19 (SPSS Inc., Chicago, IL, USA)를 사용하였다. 비단어 따라말하기, 문장 따라 말하기, 경쟁 언어 처리 과제, 매트릭스 등 다양한 구어 및 시공간적 작업기억 과제 수행 결과를 토대로 언어장애 및 또래 일반아동의 차이가 통계적으로 유의한지 살펴보기 위하여 다변량분석(MANOVA)를 사용하였다. 또한, 언어장애아동 및 또래 일반아동 집단 각각에서 표준화 언어검사 및 각 작업기억 과제들의 상관관계를 알 아보기 위해 Pearson의 적률상관계수(Pearson product monument correlation)를 산출하였으며, 다양한 구어 및 시공간적 작업기억수 행의 조합이 표준화 언어검사에 의한 언어장애 및 일반아동으로의 진단 결과와 얼마나 부합하는지 확인하기 위해 동시입력방식의 판 별분석(simultaneous estimation-discriminant analysis)을 사용하 였다.

\section{연구 결과}

\section{집단 간(언어장애아동, 일반아동) 아동의 구어 및 시공간적 작업기억 수행능력 비교}

언어장애아동 집단 및 일반아동 집단의 비단어 따라말하기, 문 장 따라말하기, 경쟁 언어 처리 과제, 그리고 매트릭스 과제수행 정 확도에 대한 결과는 Table 2와같다.

비단어 따라말하기(NWR) 과제의 단어수준 점수에서 일반아 동은 13.28점( $\mathrm{SD}=3.59)$, 언어장애아동은 12.89 점 $(\mathrm{SD}=3.32)$ 을 받 았으며, 음절수준 점수에서 일반아동은 69.28 점 $(\mathrm{SD}=9.23)$, 언어 장애아동은 68.67 점 $(\mathrm{SD}=6.52)$ 을 받았다. 이와 같은 결과가 통계적 으로 유의한지 확인한 결과, 통계적으로 유의한 집단 간 차이는 단 어 $\left(F_{(1,34)}=.738, p>.05\right)$ 및 음절 $\left(F_{(1,34)}=.820, p>.05\right)$ 수준 모두에서 나타나지 않았다

문장 따라말하기(SR) 과제에서는 문장수준 점수에서 일반아동 
이 29.33점 $(\mathrm{SD}=4.39)$, 언어장애아동이 22.67점 $(\mathrm{SD}=8.17)$, 어절수 준 점수에서 일반아동이 148.22 점 $(\mathrm{SD}=8.61)$, 언어장애아동이 135.28 점 $(\mathrm{SD}=17.43)$ 을 받았다. 이와 같은 결과가 통계적으로 유의 한지 확인한 결과, 문장 $\left(F_{(1,34)}=9.302, p<.01\right)$ 및 어절 $\left(F_{(1,34)}=7.981\right.$, $p<.01)$ 수준 모두에서 유의한 집단 간 차이가 나타났다. 즉, 언어장 애아동 집단은 또래 일반아동 집단에 비해 통계적으로 유의하게 부족한 수행을 보였다.

경쟁 언어 처리 과제(CLPT) 과제에서는 정오판단 조건에서 일반 아동이 36.72점 $(\mathrm{SD}=6.34)$, 언어장애아동이 32.50점 $(\mathrm{SD}=6.50)$, 단어회상 조건에서 일반아동이 11.67 점 $(\mathrm{SD}=7.31)$, 언어장애아동 이 5.83점 $(\mathrm{SD}=4.61)$ 을 받았다. 이와 같은 결과가 통계적으로 유의 한지 확인한 결과, 정오판단 조건에서는 일반아동 및 언어장애아동 간 유의한 수행의 차이가 나타나지 않았으나 $\left(F_{(1,34)}=3.891, p>.05\right)$, 단어회상 조건에서는 집단 간 유의한차이가 나타났다 $\left(F_{(1,34)}=8.209\right.$, $p<.01)$, 즉, 단어회상 시 언어장애아동 집단은 또래 일반아동에 비

Table 2. Between-group comparisons for working memory performances

\begin{tabular}{lccc}
\hline & LI (N=18) & NL (N=18) & $F$ \\
\hline NWR_word score & $12.89(3.32)$ & $13.28(3.59)$ & .738 \\
NWR_syllable score & $68.67(6.52)$ & $69.28(9.23)$ & .820 \\
SR_sentence score & $22.67(8.17)$ & $29.33(4.39)$ & $9.302^{*}$ \\
SR_word score & $135.28(17.43)$ & $148.22(8.61)$ & $7.981^{*}$ \\
CLPT_judgment & $32.50(6.50)$ & $36.72(6.34)$ & 3.891 \\
CLPT_word recall & $5.83(4.61)$ & $11.67(7.31)$ & $8.209^{*}$ \\
Matrix_f & $7.28(2.22)$ & $7.83(4.13)$ & 1.131 \\
Matrix_b & $10.00(3.69)$ & $8.72(3.51)$ & .252 \\
\hline
\end{tabular}

Values are presented as mean (SD).

$\mathrm{NL}=$ children with normal language; $\mathrm{LI}=$ children with language impairment; NWR= nonword repetition, $\mathrm{SR}=$ sentence repetition; CLPT = Competing Language Processing Task; Matrix_f=matrix forward; Matrix_b=matrix backward. ${ }^{*} p<.01$.
해 통계적으로 유의하게 부족한 수행을 보였다.

두 집단간 시공간적 작업기억 능력-매트릭스(Matrix) 과제에서는 순행 조건에서 일반아동이 7.83점 $(\mathrm{SD}=4.13)$, 언어장애아동이 7.28 점 $(\mathrm{SD}=2.22)$ 을 받았으며, 역행 조건에서 일반아동이 8.72점 $(\mathrm{SD}=$ $3.51)$, 언어장애아동이 10.00 점 $(\mathrm{SD}=3.69)$ 을 받았다. 이와 같은 결 과가 통계적으로 유의한지 확인한 결과, 순행 $\left(F_{(1,34)}=1.131, p>.05\right)$ 및 역행 $\left(F_{(1,34)}=.252, p>.05\right)$ 조건 모두에서 통계적으로 유의한 집 단 간 수행의 차이가 나타나지 않았다. 이에 대한 결과를 Table 2에 제시하였다.

\section{각 집단(일반아동, 언어장애아동)의 표준화 언어검사(REVT-R, REVT-E) 결과와 작업기억 하위과제 수행 간 상관관계}

일반아동 집단에서 수용어휘력(REVT-R)과 유의한 상관관계를 보이는 것은 구어 작업기억 과제 중에서는 CLPT_judgment $(r=.531$, $p<.05)$, NWR_word $(r=.567, p<.05)$, 시공간적 작업기억 과제 중 에서는 Matrix_b $(r=.474, p<.05)$, Matrix_f $(r=.735, p<.01)$ 였으 며, 표현어휘력(REVT-E)과 유의한 상관관계를 보이는 것은 시공간 적 작업기억 과제인 Matrix_f $(r=.554, p<.05)$ 였다. 이에 대한 결과 는 Table 3과같다.

단순언어장애 아동 집단에서는 수용어휘력(REVT-R)과 유의한 상관관계를 보이는 과제가 없었으며, 표현어휘력(REVT-E)과 유의한 상관관계를 보이는 것은 CLPT_judgment $(r=.645, p<.01), \mathrm{NWR}$ syllable $(r=.540, p<.05)$ 이었다. 이에 대한 결과는 Table 4 와 같다.

\section{구어 및 시공간적 작업기억 하위유형의 조합을 통한 언어장애 판별력 탐색}

본 연구를 위해 사용된 구어 및 시공간적 작업기억 과제의 하위 유형의 조합으로 언어장애 및 또래 일반아동 집단 각각을 잘 판별

Table 3. The correlation coefficients among tasks in children with normal language

\begin{tabular}{|c|c|c|c|c|c|c|c|c|c|}
\hline & REVT-R & REVT-E & CLPT_judgment & CLPT_recall & NWR_word & NWR_syllable & SR_sentence & SR_word & Matrix_b \\
\hline REVT-E & .431 & & & & & & & & \\
\hline CLPT_judgment & $.531^{*}$ & .263 & & & & & & & \\
\hline CLPT_recall & .385 & .405 & $.673^{* *}$ & & & & & & \\
\hline NWR_word & $.567^{*}$ & .364 & .404 & $.508^{*}$ & & & & & \\
\hline NWR_syllable & .418 & .374 & .257 & .394 & $.939^{* *}$ & & & & \\
\hline SR_sentence & .233 & .032 & $.612^{* *}$ & .368 & $.664^{* *}$ & $.608^{* *}$ & & & \\
\hline SR_word & .321 & .124 & $.631^{* *}$ & $.574^{*}$ & $.644^{* *}$ & $.540^{*}$ & $.848^{* *}$ & & \\
\hline Matrix_b & $.474^{*}$ & .441 & $.488^{*}$ & $.803^{* *}$ & $.598^{* *}$ & $.509 *$ & .411 & $.533^{*}$ & \\
\hline Matrix_f & $.735^{* *}$ & $.554^{*}$ & .364 & $.508^{*}$ & .443 & .328 & .065 & .181 & $.758^{* *}$ \\
\hline
\end{tabular}

REVT=Receptive \& Expressive Vocabulary Test (Kim, Hong, Kim, Jang, \& Lee, 2010); CLPT=Competing Language Processing Task; NWR=nonword repetition; SR=sentence repetition; Matrix_b=matrix backward; Matrix_f=matrix forward.

${ }^{*} p<.05,{ }^{* *} p<.01$. 
Table 4. The correlation coefficients among tasks in children with language impairment

\begin{tabular}{|c|c|c|c|c|c|c|c|c|c|}
\hline & REVT-R & REVT-E & CLPT_judgment & CLPT_recall & NWR_word & NWR_syllable & SR_sentence & SR_word & Matrix_b \\
\hline REVT-E & .323 & & & & & & & & \\
\hline CLPT_judgment & .299 & $.645^{* *}$ & & & & & & & \\
\hline CLPT_recall & .300 & .311 & $.659 * *$ & & & & & & \\
\hline NWR_word & .237 & .351 & .362 & .314 & & & & & \\
\hline NWR_syllable & .259 & $.540^{*}$ & .397 & .457 & $.783^{* *}$ & & & & \\
\hline SR_Sentence & .292 & .416 & .466 & $.696^{* *}$ & $.675^{* *}$ & $.779 * *$ & & & \\
\hline SR_Word & .175 & .407 & .439 & $.664^{* *}$ & $.633^{* *}$ & $.755^{* *}$ & $.961^{* *}$ & & \\
\hline Matrix_b & .293 & -.037 & -.020 & .429 & .120 & .100 & .279 & .225 & \\
\hline Matrix_f & .144 & -.349 & -.169 & .022 & -.203 & -.286 & -.053 & -.058 & $.531^{*}$ \\
\hline
\end{tabular}

REVT=Receptive \& Expressive Vocabulary Test (Kim, Hong, Kim, Jang, \& Lee, 2010); CLPT =Competing Language Processing Task; NWR=nonword repetition; SR=sentence repetition; Matrix_b=matrix backward; Matrix_f=matrix forward. ${ }^{*} p<.05,{ }^{* *} p<.01$.

Table 5. Classification table from discriminant analysis

\begin{tabular}{|c|c|c|c|c|c|c|}
\hline Model & $x^{2}$ & Discriminant loading & $\begin{array}{c}\text { Specificity } \\
(\%)\end{array}$ & $\begin{array}{c}\text { Sensitivity } \\
(\%)\end{array}$ & $\begin{array}{l}\text { Total } \\
(\%)\end{array}$ & $p$-value \\
\hline 1 & 26.539 & $\begin{array}{r}\text { NWR_word (.048) } \\
\text { NWR_syllable (.033) } \\
\text { SR_sentence (.439) } \\
\text { SR_word (.406) } \\
\text { CLPT_judgment (.284) } \\
\text { CLPT_recall }(.412) \\
\text { Matrix_f (.072) } \\
\text { Matrix_b (-.153) }\end{array}$ & 94.4 & 83.3 & 88.9 & $<.01$ \\
\hline 2 & 20.041 & $\begin{array}{r}\text { NWR_word (.062) } \\
\text { SR_sentence (.561) } \\
\text { CLPT_recall (.527) } \\
\text { Matrix_b (-.195) }\end{array}$ & 88.9 & 83.3 & 86.1 & $<.01$ \\
\hline
\end{tabular}

할 수 있는지 알아보기 위해 동시입력방식의 판별분석(simultaneous estimation-discriminate analysis)을 실시하였다. 그 결과, 모든 과제들을 입력한 모형 1에서 일반아동을 일반아동으로 판별하는 특이도(specificity)는 $94.4 \%$, 언어장애아동을 언어장애아동으로 판별하는 민감도(sensitivity)는 $83.3 \%$ 로 원 집단 케이스 중 총 $88.9 \%$ 가 올바르게 분류될 수 있는 것으로 나타났다 $\left(\chi^{2}=26.539, p<.01\right)$. 이는 Plante와 Vance (1994)의 연구에서 민감도와 특이도가 $80 \%$ $89 \%$ 사이일 때, '타당한(fair) 판별', $90 \%$ 이상일 때 ‘좋은(good) 판별' 로 해석할 수 있다고 보았으므로 이에 근거하여 '타당한(fair) 판별' 조합인 것으로 판단할 수 있다.

모형 2에서는 모형 1의 각 과제(NWR, SR, CLPT, Matrix) 중에 서 판별의 효율성을 위하여 요구되는 정보를 최소화하고자, 채점방 식이나 조건에 따라 상대적으로 구조행렬의 판별적재값(각 변수와 표준화된 정준판별함수 간의 상관관계 값)의 절대값이 높은 채점 방식 또는 조건을 선정하여 입력하였다. 즉, NWR과제에서는 단어 점수(word), SR과제에서는 문장점수(sentence), CLPT과제에서는 단어회상점수(recall), Matrix과제에서는 역행조건(backward)을 입력하였다. 그 결과, 일반아동을 일반아동으로 판별하는 특이도는 $88.9 \%$, 언어장애아동을 언어장애아동으로 판별하는 민감도는 $83.3 \%$ 로 원 집단 케이스 중 총 $86.1 \%$ 가 올바르게 분류될 수 있는 것 으로 나타났으며 $\left(\chi^{2}=20.041, p<.01\right)$, 요구되는 정보를 최소화했던 모형 2 역시 Plante와 Vance (1994)의 기준에 따른다면, '타당한 판 별'로 볼수 있다. 이에 대한 세부적인 결과는 Table 5 와 같다.

\section{논의 및 결론}

본 연구에서 만 5-6세의 언어장애아동 및 또래 일반아동들의 작 업기억 능력을 측정하기 위해 구어 및 시공간적 작업기억으로 나누 고 이러한 과제들 중에서 두 집단을 잘 변별해주는 유용한 임상적 도구 및 하위항목이 존재하는지, 언어장애아동 및 또래 일반아동 집단 각각에서 표준화 언어검사와 유의한 상관관계를 보이는 작업 기억 과제 하위유형은 무엇인지, 그리고 언어장애 판별을 위해 유 용한 구어 및 시공간적 작업기억 하위항목의 조합이 표준화 언어검 사에 의해 분류된 언어장애 및 일반아동 집단 분류의 결과와 얼마 나 부합할 수 있는지 그 가능성을 확인해보고자 하였다.

첫째, 구어 작업기억 과제 중 비단어 따라말하기(NWR)에서는 장애 및 비장애 집단 간 차이가 나타나지 않았으나, 문장 따라말하 기(SR)에서는 집단 간 차이가 유의하였다. 이는 문장 따라말하기 과제가 비단어 따라말하기 과제에 비해 높은 판별력을 지닌 과제임 을 입증하였던 국내외 선행연구와 일치하는 결과이다(Conti-Ramsden et al., 2001; Oh \& Yim, 2013). 이는 언어장애아동의 핵심적인 어려움이 '언어'에 있으므로 상대적으로 기존 어휘 또는 구문 구조 에 대한 지식 및 이해와 같은 잔존 능력으로부터 최대한 분리된 음 운작업기억능력을 측정하고자 하였던 '비단어 따라말하기'에 비 
해, 축적되어 온 언어학적 지식 및 이해능력을 더욱 요구하는 '문장 따라말하기 과제'에서 집단 간 격차는 더욱 유의하게 나타날 수 있 는 것으로 보인다.

또한, 의미적인 정오판단 및 단어회상을 복합적으로 요구하는 경 쟁 언어 처리 과제(CLPT)의 경우, 정오판단에서는 집단 간 차이가 유의하지 않았으나, 단어회상에서는 유의한 차이를 보였다. 이러한 결과는 언어장애아동들이 또래 일반아동에 비해 경쟁 언어 처리 과제 수행에서 문장이해 처리 시에는 부족함이 없었으나, 문장의 마지막 단어(목표단어)들을 회상할 때에는 유의한 어려움을 보였 음을 보고했던 선행 연구들의 결과와 일치한다(Ellis Weismer et al., 1999; Ellis Weismer \& Thordardottir, 2002). 특히 언어장애아 동들은 한 가지 처리만을 요구하는 과제에서는 또래 아동에 비해 큰 어려움이 나타나지 않을 수 있지만, 동시적, 복합적 처리 과제에 서 또래 비장애 아동들에 비해 점수가 큰 폭으로 저하될 수 있다 (Montgomery, 2000). 즉, 문장이해 처리와 함께 단어회상이 연속 적 또는 동시적으로 요구되면, 먼저 수행하게 되는 문장이해 처리 수행으로 인해 단어회상을 위한 아동의 인지적 부하가 가중되므 로 작업기억 용량 및 처리 효율의 저하가 나타날 수 있는 것이다(Ellis Weismer \& Thordardottir, 2002; Montgomery, 2000).

시공간적 작업기억 능력을 측정하고자 했던 매트릭스(Matrix)과 제에서는 순행(forward) 및 역행(backward) 조건 모두 두 집단 간 유의한 차이가 나타나지 않았다. 본 연구의 결과로부터 언어장애아 동들의 작업기억 결함은 비언어적인 자극을 제시한 시공간적 작업 기억 과제인 매트릭스에서는 나타나지 않았고, 문장 따라말하기와 경쟁 언어 처리 과제와 같은 구어(언어) 작업기억 과제에서 유의하 게 나타났다. 즉, 시공간적 작업기억 과제 수행에서 본 연구의 언어 장애아동들은 수행능력을 보존하고 있으며, 적어도 시공간적 영역 안에서는 또래 비장애 아동들에 비해 두드러진 어려움이 나타나지 않는 것으로 분석된다. 이러한 특징은 언어 및 비언어 모두에서 전 반적인 처리 능력에 제한을 보인다고 언급했던 Ullman과 Pierpont (2005)의 가설과는 상반되는 것이다. Ullman과 Pierpont (2005)는 언어장애아동들에게 언어적인 결함뿐 아니라 비언어적인 처리 결 함 역시 존재하기 때문에 이러한 처리 능력이나 속도에 제한이 있 다는 가설로 이들의 어려움을 설명하고자 했다. 이들이 주장한 전 반적 처리 제한(general processing deficits) 또는 절차적 결함 가설 (procedural deficit hypothesis)에 따르면, 특히 언어장애아동들은 '순서'와 관련된 운동기술에도 결함이 있는 것으로 보고하였다(Bishop, 2002; Hill 2001; Ullman \& Pierpont, 2005). 그러나, 본 연구에 서 매트릭스 과제 수행력을 알아보기 위해 정확도만을 측정하였으 므로, 후속 연구에서 정확도뿐만 아니라 반응속도 또한 함께 측정
해본다면 절차적 결함 가설에서 주장하는 이들의 전반적인 결함을 보다 폭 넓게 검증해볼 수 있을 것으로 보인다.

둘째, 언어장애 및 또래 일반아동 집단 각각에서 표준화 언어검 사(REVT-R, REVT-E)와 통계적으로 유의한 상관을 보이는지 확 인하였다. 그 결과, 일반아동 집단에서는 수용어휘력(REVT-R)과 구어작업기억 과제인 'CLPT_judgment', 'NWR_word', 시공간적 작업기억 과제인 'Matrix_b', 'Matrix_f'가 유의한 상관을 보였으 며, 표현어휘력(REVT-R)과 시공간적 작업기억 과제인 'Matrix_f' 가 유의한 상관을 보였다. 즉, 일반아동 집단의 어휘력은 구어 및 시 공간적 작업기억 모두 통계적으로 유의한 상관을 보였다. 이는 이 들의 언어처리를 위해 구어 및 시공간적 작업기억 점수가 모두 통계 적으로 유의하게 연관성을 나타내는 것으로 보인다. 특히, 시공간적 작업기억(Matrix-f)은 수용어휘력(REVT-R) 및 표현어휘력(REVTE) 모두와 유의한 상관을 보였으며, 특히 수용어휘력(REVT-R)과 가장 높은 상관관계를 보였다. 이는 일반아동 집단에서 비언어적 자극이 사용된 시공간적 작업기억(Matrix-f)과제는 다양한 구어 작업기억 과제 $(\mathrm{NWR}, \mathrm{SR}, \mathrm{CLPT})$ 들과 마찬가지로 어휘력과 정적 상관관계를 나타낼 수 있음을 보여준다. Yim, Kim 그리고 Yang (2015)에 따르면, 시공간적 작업기억(Matrix)과제는 청각적 정보를 거의 자동적으로 부호화할 수 있는 구어 작업기억 과제에 비해 제 시되는 자극이 즉각적인 언어로 부호화될 수 없으므로 상대적으 로 높은 부하를 요하는 과제로 보았다. 즉, 시각 또는 비언어적 정보 일지라도 효율적인 과제 수행을 위해 부하가 높은 작업기억 영역이 활용 가능하다면, 효율적인 언어 및 어휘처리를 위해 긍정적인 역 할을 할 수 있는 것이다(Gillam et al., 1998; Kamhi et al., 1984).

한편, 언어장애아동 집단에서 수용어휘력(REVT-R)과 유의한 상관관계를 보이는 것은 나타나지 않았으며, 표현어휘력(REVT-E) 과 유의한 상관관계를 보이는 것은 구어 작업기억 과제인 '경쟁언어 처리과제-정오판단(CLPT_judgment)', '비단어 따라말하기-음절 (NWR_syllable)'인 것으로 나타났다. 이처럼 표현어휘력(REVT-E) 과 구어 작업기억 과제들이 긴밀한 상관을 나타냈으나, 시공간적 작업기억 과제는 이들의 언어검사 점수와는 유의한 상관이 나타나 지 않아 또래 일반아동 집단과 차이를 보였다. 이는 시공간적 작업 기억 과제의 수행에서 언어장애 및 일반아동 집단 간 차이가 통계 적으로 유의하지 않아 언어장애아동들에게 시공간적 작업기억 능 력이 상대적으로 잔존하는 것으로 나타났던 분산분석의 결과와 비교하여 주목해보아야 할 점이기도 하다. 선행연구에서도 일반아 동의 경우 시각적 정보를 구어적 형태로 자유롭게 전환 또는 변형 시킬 수 있었으나, 언어장애아동들은 시각적 정보 처리 및 시각적 심상을 생성해내는 능력 그 자체에는 어려움이 없었지만, 어휘 이 
해와 같은 언어과제 수행 시 시각적 정보를 적절한 구어적 형태로 변형시키는 것에 어려움을 보이고, 비효율적 시각적 처리를 수행하 는 것으로 보았다(Kamhi et al., 1984). 그러므로, 이들의 언어능력 증진을 위해서는 잔존하는 시공간적 작업기억 능력이 비효율적으 로 활용될 수 있는 가능성을 축소하는 것과 동시에, 이들의 언어 능 력과 긴밀한 상관관계를 보였던 구어 작업기억 능력의 증진을 위한 방안을 강구해야 할 것으로 보인다(Gillam et al., 1998; Montgomery, 2002).

셋째, 본 연구를 위해 사용된 모든 구어 및 시공간적 작업기억 과 제 하위유형들을 입력한 모형 1 은 높은 판별력을 나타낸 조합인 것 으로 나타났다. 즉, 구어 및 시공간적 작업기억 과제들의 조합은 기 존 표준화 언어검사에 의한 언어장애 및 비장애 판별력에 준하는 타당한 판별도구로서의 가능성을 지닌 것으로 보인다. 뿐만 아니 라, 판별의 효율성을 위하여 요구되는 정보를 최소화하고자, 채점 방식이나 조건에 따라 상대적으로 구조행렬의 판별적재값(각 변수 와 표준화된 정준판별함수 간의 상관관계 값)의 절대값이 높은 채 점방식 또는 조건을 선정하여 '비단어 따라말하기(NWR)'는 단어 점수, '문장 따라말하기(SR)'는 문장점수, '경쟁 언어 처리 과제(CLPT)' 는 단어회상점수, '매트릭스(Matrix)'는 역행(backward)조건, 총 4 가지의 변수를 입력했던 모형 2 역시 타당한 판별력을 지닌 것으로 분석되었다.

결론적으로, 언어장애의 유무를 판단하기 위하여 유용한 임상 적 지표로 확인된 구어 및 시공간적 작업기억 과제들의 조합이 언 어장애 및 비장애 판별 시 유용한 도구로 활용될 수 있는 가능성을 지닌 것으로 보인다. 후속연구에서는 언어장애 및 또래 일반아동 뿐만 아니라 대상 아동을 언어연령일치 일반아동으로 확장하여 살 펴본다면 구어 및 시공간적 작업기억 과제의 판별력에 대해 보다 심층적인 논의가 가능할 것으로 보인다.

\section{REFERENCES}

Ahn, J. S., \& Kim, Y. T. (2000). The effect of syntactic complexity on sentence repetition performance and intelligibility between specific language impairment and normal children. Korean Journal of Speech Sciences, 7, 249262.

Archibald, L. M., \& Gathercole, S. E. (2006). Visuospatial immediate memory in specific language impairment. Journal of Speech, Language, and Hearing Research, 49, 265-277.

Archibald, L. M., \& Gathercole, S. E. (2007). Nonword repetition in specific language impairment: more than a phonological short-term memory defi- cit. Psychonomic Bulletin \& Review, 14, 919-924.

Bavin, E. L., Wilson, P. H., Maruff, P., \& Sleeman, F. (2005). Spatio-visual memory of children with specific language impairment: evidence for generalized processing problems. International Journal of Language \& Communication Disorders, 40, 319-332.

Bishop, D. V. (1997). Cognitive neuropsychology and developmental disorders: uncomfortable bedfellows. Quarterly Journal of Experimental Psychology: Section A, 50, 899-923.

Bishop, D. V. (2002). Motor immaturity and specific speech and language impairment: evidence for a common genetic basis. American Journal of Medical Genetics, 114, 56-63.

Bishop, D. V. (2006). Beyond words: phonological short-term memory and syntactic impairment in specific language impairment. Applied Psycholinguistics, 27, 545-547.

Bishop, D. V., North, T., \& Donlan, C. (1996). Nonword repetition as a behavioural marker for inherited language impairment: evidence from a twin study. Journal of Child Psychology and Psychiatry, 37, 391-403.

Botting, N., \& Conti-Ramsden, G. (2001). Non-word repetition and language development in children with specific language impairment (SLI). International Journal of Language \& Communication Disorders, 36, 421-432.

Calderon, J., \& Gutierrez-Clellen, V. (2003). Nonword repetition in emerging bilingual children with language impairment. Proceedings of the 4th International Symposium on Bilingualism, Tempe, AZ.

Conti-Ramsden, G., Botting, N., \& Faragher, B. (2001). Psycholinguistic markers for specific language impairment (SLI). Journal of Child Psychology and Psychiatry, 42, 741-748.

Conti-Ramsden, G. (2003). Processing and linguistic markers in young children with specific language impairment (SLI). Journal of Speech, Language, and Hearing Research, 46, 1029-1037.

Dollaghan, C., \& Campbell, T. F. (1998). Nonword repetition and child language impairment. Journal of Speech, Language, and Hearing Research, 41, 1136-1146.

Ellis Weismer, S., \& Thordardottir, E. (2002). Cognition and language. In P. J. Accardo, B. T. Rogers, \& A. J. Capute (Eds.), Disorders of language development (pp. 21-37). Baltimore, MD: York Press.

Gathercole, S. E., \& Pickering, S. J. (2000). Working memory deficits in children with low achievements in the national curriculum at 7 years of age. British Journal of Educational Psychology, 70, 177-194.

Gathercole, S. E., Willis, C. S., Baddeley, A. D., \& Emslie, H. (1994). The children's test of nonword repetition: a test of phonological working memory. 
Memory, 2, 103-127.

Gaulin, C. A., \& Campbell, T. F. (1994). Procedure for assessing verbal working memory in normal school-age children: some preliminary data. Perceptual and Motor Skills, 79, 55-64.

Gillam, R. B., Cowan, N., \& Marler, J. A. (1998). Information processing by school-age children with specific language impairment: evidence from a modality effect paradigm. Journal of Speech, Language, and Hearing Research, 41, 913-926.

Hick, R., Botting, N., \& Conti-Ramsden, G. (2005). Cognitive abilities in children with specific language impairment: consideration of visuo-spatial skills. International Journal of Language \& Communication Disorders, 40, 137-149.

Hill, E. L. (2001). Non-specific nature of specific language impairment: a review of the literature with regard to concomitant motor impairments. International Journal of Language \& Communication Disorders, 36, 149-171.

Hwang, M. (2014). Working memory of children with reading comprehension difficulty: sentence repetition and nonword repetition. Korea Journal of Learning Disabilities, 11, 53-72.

Johnston, J. R., \& Ellis Weismer, S. (1983). Mental rotation abilities in language-disordered children. Journal of Speech, Language, and Hearing Research, 26, 397-403.

Just, M. A., \& Carpenter, P. A. (1992). A capacity theory of comprehension: individual differences in working memory. Psychological Review, 99, 122 149.

Kail, R., \& Salthouse, T. A. (1994). Processing speed as a mental capacity. Acta Psychologica, 86, 199-225.

Kamhi, A. G., \& Catts, H. W. (1986). Toward an understanding of developmental language and reading disorders. Journal of Speech and Hearing Disorders, 51, 337-347.

Kamhi, A. G., Catts, H. W., Koenig, L. A., \& Lewis, B. A. (1984). Hypothesistesting and nonlinguistic symbolic abilities in language-impaired children. Journal of Speech and Hearing Disorders, 49, 169-176.

Kamhi, A. G., Catts, H. W., Mauer, D., Apel, K., \& Gentry, B. F. (1988). Phonological and spatial processing abilities in language- and reading-impaired children. Journal of Speech and Hearing Disorders, 53, 316-327.

Kim, H., \& Yim, D. (2012). The performance on working memory span task in children with high-function autism. Korean Journal of Communication Disorders, 17, 451-465.

Kim, Y. T., Hong, G. H., Kim, K. H., Jang, H. S., \& Lee, J. Y. (2009). Receptive \& expressive vocabulary test (REVT). Seoul: Seoul Community Rehabilita- tion Center.

Lee, Y., Yim, D., \& Sim, H. (2012). Phonological processing skills and its relevance to receptive vocabulary development in children with early cochlear implantation. International Journal of Pediatric Otorhinolaryngology, 76, $1755-1760$.

Leonard, L. B. (1998). Children with specific language impairment. Cambridge, MA: MIT Press.

MacWhinney, B., Feldman, H., Sacco, K., \& Valdés-Pérez, R. (2000). Online measures of basic language skills in children with early focal brain lesions. Brain and Language, 71, 400-431.

Mainela-Arnold, E., Evans, J. L., \& Coady, J. (2010). Beyond capacity limitations II: effects of lexical processes on word recall in verbal working memory tasks in children with and without specific language impairment. Journal of Speech, Language, and Hearing Research, 53, 1656-1672.

Marini, A., Gentili, C., Molteni, M., \& Fabbro, F. (2014). Differential verbal working memory effects on linguistic production in children with specific language impairment. Research in Developmental Disabilities, 35, 3534 3542 .

Marton, K. (2008). Visuo-spatial processing and executive functions in children with specific language impairment. International Journal of Language \& Communication Disorders, 43, 181-200.

Miller, C. A., Kail, R., Leonard, L. B., \& Tomblin, J. B. (2001). Speed of processing in children with specific language impairment. Journal of Speech, Language, and Hearing Research, 44, 416-433.

Montgomery, J. W. (2000). Relation of working memory to off-line and realtime sentence processing in children with specific language impairment. Applied Psycholinguistics, 21, 117-148.

Montgomery, J. W. (2002). Understanding the language difficulties of children with specific language impairments: does verbal working memory matter? American Journal of Speech-Language Pathology, 11, 77-91.

Moon, S. B., \& Byun, C. J. (2003). Korean Kaufman assessment battery for children (K-ABC). Seoul: Hakjisa.

Newcomer, P. L., \& Hammill, D. D. (2008). Test of language development: primary, 4th edition (TOLD-P 4). Austin, TX: Pro-Ed.

Oh, D. Y., \& Yim, D. (2013). Non-word repetition and sentence repetition performance in 2-3 years old late talkers and normal children. Communication Sciences \& Disorders, 18, 277-287.

Plante, E., \& Vance, R. (1994). Selection of preschool language tests: a databased approach. Language, Speech, and Hearing Services in Schools, 25, 15 24. 
Semel, E. M., Wiig, E., \& Secord, W. (1989). CELF-R screening test. San Antonio, TX: Psychological Corporation.

Stokes, S. F., Wong, A. M., Fletcher, P., \& Leonard, L. B. (2006). Nonword repetition and sentence repetition as clinical markers of specific language impairment: the case of Cantonese. Journal of Speech, Language, and Hearing Research, 49, 219-236.

Ullman, M. T., \& Pierpont, E. I. (2005). Specific language impairment is not specific to language: the procedural deficit hypothesis. Cortex, 41, 399-433.

Van der Lely, H. K., \& Howard, D. (1993). Children with specific language impairment: linguistic impairment or short-term memory deficit? Journal of Speech, Language, and Hearing Research, 36, 1193-1207.

Ellis Weismer, S., Evans, J., \& Hesketh, L. J. (1999). An examination of verbal working memory capacity in children with specific language impairment. Journal of Speech, Language, and Hearing Research, 42, 1249-1260.
Ellis Weismer, S., Tomblin, J. B., Zhang, X., Buckwalter, P., Chynoweth, J. G., $\&$ Jones, M. (2000). Nonword repetition performance in school-age children with and without language impairment. Journal of Speech, Language, and Hearing Research, 43, 865-878.

Yang, Y., Yim, D., Kim, S., \& Han, J. (2013). The relationship among receptive vocabulary, non-word repetition, and quick incidental learning in preschoolers with and without delay in vocabulary development. Communication Sciences \& Disorders, 18, 379-391.

Yim, D., Kim, S. Y., \& Yang, Y. (2015). Factor analysis of working memory tasks based on information processing characteristics: predictive factors of receptive vocabulary and quick incidental learning in children with typically developing and receptive vocabulary delay. Communication Sciences \& Disorders, 20, 304-318. 


\section{국문초록}

\section{언어장애아동 판별을 위한 구어 및 시공간적 작업기억의 효용성 탐색}

임동선 · 김영태 · 양윤희

이화여자대학교 언어병리학과

배경 및 목적: 본 연구에서는 언어장애의 유무를 판단하는데 아동의 구어, 시공간적 작업기억 과제 수행이 유용한 도구가 될 수 있는 지 알아보고, 이러한 조합이 표준화 언어검사에 준하는 판별력을 지니는지 살펴보고자 하였다. 방법: 만 5-6세의 언어장애아동 18명, 생활연령을 일치한 또래 일반아동 18 명 총 36명을 대상으로 구어적 작업기억(nonword repetition/sentence repetition/Competing Language Processing Task), 시공간적 작업기억(Matrix) 과제 수행을 분석하였다. 결과분석은 다변량분석, Pearson의 적률상관계수 및 판 별분석을 실시하였다. 결과: 분산분석 결과, 그룹 간 차이가 유의했던 과제는 '문장 따라말하기(SR)-단어 및 문장 점수, '경쟁 언어 처리 과제(CLPT)-단어회상 점수’로 나타났으며, 본 연구의 모든 과제들을 입력하였을 때, 일반아동을 일반아동으로 판별하는 특이도(specificity)는 94.4\%, 언어장애아동을 언어장애아동으로 판별하는 민감도(sensitivity)는 $83.3 \%$ 로 원 집단 케이스 중 총 $88.9 \%$ 가 올바르게 분류될 수 있는 것으로 나타났다. 논의 및 결론: 결론적으로, 본 연구를 통해 언어장애의 유무를 판단하기 위한 전제로 유용한 임상적 지표로 확인된 구어 및 시공간적 작업기억 과제들의 조합이 표준화 언어검사 결과에 준하는 높은 판별력을 지닐 수 있는 것으로 분석된 다.

핵심어: 구어 작업기억, 시공간적 작업기억, 언어장애, 판별분석

본 연구는 2014년 정부(교육부)의 재원으로 한국연구재단의 지원을 받아 수행된 연구임(NRF-2014S1A5A8017863).

본 연구는 정부의 재원으로 BK21 Plus사업의 지원을 받아 수행된 연구임.

본 연구는 2015학년도 이화여자대학교 대학원 장학금 지원에 의한 논문임.

\section{참고문헌}

김영태, 홍경훈, 김경희, 장혜성, 이주연(2009). 수용·표현어휘력검사(REVT). 서울: 서울장애인종합복지관. 김희진, 임동선(2012). 과제 난이도에 따른 고기능 자폐아동의 작업기억 수행능력. 언어청각장애연구, 17, 451-465.

문수백, 변창진(2003). K-ABC 교육·심리측정도구(Korean-Kaufman assessment battery for children). 서울: 학지사.

안지숙, 김영태(2000). 단순언어장애 아동과 정상아동의 구문적 난이도에 따른 문장 따라말하기: 수행력 및 명료도 비교. 음성과학, 7, 249-262.

양윤희, 임동선, 김신영, 한지윤(2013). 학령 전 어휘발달지체 및 일반 아동의 비단어 따라말하기, 빠른 우연학습(Quick Incidental Learning)과수용

어휘와의 관계. 언어청각장애연구, $18,379-391$.

오다연, 임동선(2013).2-3세 말 늦은 아동과 정상 아동의 비단어 따라말하기와 문장 따라말하기 수행 능력. 언어청각장애연구, 18, 277-287.

임동선, 김신영, 양윤희(2015). 정보처리 특성에 따른 작업기억 과제의 탐색적 요인분석: 일반아동 및 수용어휘지체 아동의 수용 어휘력 및 빠른우연

학습 예측요인. 언어청각장애연구, 20, 304-318.

황민아 (2014). 읽기이해부진 아동의 작업기억 특성: 문장 따라말하기 및 비단어 따라말하기 검사를 중심으로. 학습장애연구, 11, 53-72. 